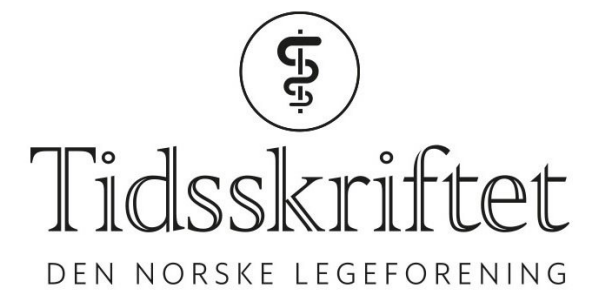

\title{
Riktige prioriteringer ved sepsis
}

LEDER

\section{STEINAR SKREDE}

E-post: steinar.skrede@helse-bergen.no

Steinar Skrede er assisterende avdelingsdirektør ved Medisinsk avdeling, Haukeland universitetssjukehus og professor II ved Klinisk institutt 2, Universitetet i Bergen. Han var uavhengig fagrevisor for Statens helsetilsyn i tilsynet Stopp sepsis (2016-18).

Forfatteren har fylt ut ICMJE-skjemaet og oppgir ingen interessekonflikter.

Tilsyn av sykehusene sin sepsisbehandling har ført til forbedringer, men mye gjenstår.

Statens helsetilsyn gjennomførte i 2016-18 tilsyn av sepsisbehandlingen i akuttmottak i hele landet, det hittil mest omfattende i somatiske sykehus (1). De siste årene har det blitt rapportert om flere hendelser ved alvorlige infeksjoner, der manglende kompetanse og rutiner har blitt påvist. At tilsynet ville identifisere forbedringsområder, var derfor sannsynlig.

Forekomsten av sepsis i Norge har vært lite studert, men nye data fra 2017 dokumenterer omfanget. Sepsis utgjør rundt $1 \%$ av alle innleggelser i somatiske sykehus, pasientene opptar 3,5\% av sengekapasiteten, dødeligheten er uakseptabelt høy (rundt $25 \%$ ) og sepsis er årsak til minst hvert syvende dødsfall i sykehus (2).

Tilsynsmyndighetene gjorde et viktig funn før selve tilsynet begynte: Ikke ett sykehus kunne legge frem data om forekomsten eller tallfeste kvalitetsmål på sine tjenester ved sepsis. Dette tyder på at en av årsakene til uakseptable behandlingsresultater har vært en utstrakt neglisjering av alvorlige infeksjoner i spesialisthelsetjenesten.

Ikke ett sykehus kunne legge frem data om forekomsten eller tallfeste kvalitetsmål på sine tjenester ved sepsis

Ingen av sykehusene i tilsynsundersøkelsen nådde målsetningen om å gi antibiotika intravenøst innen 6o minutter etter ankomst hos pasienter med infeksjon og organsvikt, slik det er nedfelt i sykehusenes retningslinjer (3). I artikkelen som nå publiseres $\mathrm{i}$ Tidsskriftet, beskriver Trydal og medarbeidere det systematiske forbedringsarbeidet som er gjort etter at det ble stadfestet avvik i behandlingen av pasienter med sepsis ved Ullevål sykehus (4). Deres tall viser at flertallet av sepsispasientene nå blir behandlet med antibiotika innen én time. Dette vil antagelig bedre prognosen for mange pasienter, ettersom flere studier har vist assosiasjon mellom død og tid før påbegynt antibiotikabehandling.

Selv om sepsisbehandlingen ved Ullevål sykehus ble bedre, ble ikke målet om rask behandling nådd for alle pasientene. Men for mange pasienter som er i livets siste fase og som legges inn i sykehus på grunn av alvorlig infeksjon, er målet med innleggelsen først og fremst at de skal få hjelp til å dø i ro og med verdighet - ikke å gjennomgå plagsomme, 
kostbare og nytteløse tiltak.

Tilsynet viste at ingen av sykehusene som brukte de gamle SIRS-kriteriene ved alvorlig infeksjon klarte å prioritere sine oppgaver rett (5). Nye internasjonale sepsisdefinisjoner og skåringssystemer ble publisert midt i perioden tilsynet pågikk. Både studien fra Ullevål sykehus (4) og data fra St. Olavs hospital (6) viser svakheter ved skåringssystemet quickSOFA. Trydal og medarbeidere diskuterer også risikoen for overdreven bruk av bredspektrede antibiotika ved sepsis. Den autoritative infeksjonsforeningen i USA argumenterer mot retningslinjer der samme antibiotikabehandling anbefales til alle med sepsis (7). Dette er blant spørsmålene man må ta stilling til i arbeidet med sepsiskapitlet $\mathrm{i}$ Nasjonal retningslinje for bruk av antibiotika i spesialisthelsetjenesten, som nå skal revideres. Konsensus om innholdet i utgaven er viktig for å unngå unødig mistro til den (8).

Studien fra Trydal og medarbeidere bidrar med kunnskap til bruk i forbedringsarbeid andre steder, bl.a. mottak med høy pasientstrøm og i kirurgiske mottak, som får 10-20 \% av alle pasienter med sepsis. Ullevål sykehus gjorde tiltak innenfor egne rammer, og deres prioriteringer fremstår som gjennomførbare og i tråd med helsepolitiske føringer.

Det neste landsomfattende tilsynet i somatiske sykehus er alt i gang. Myndighetene utfører nå tilsyn av pasienter som tidlig i oppholdet mottar behandling i en avdeling eller sengepost uten optimal fagspesifikk kompetanse. At myndighetene holder øye med sykehusenes praksis og prioriteringer, er verdifullt. For sepsispasienter kan det stå om sjansen til å overleve.

\section{LITTERATUR:}

1. Sepsis - ingen tid å miste. Oppsummering av landsomfattende tilsyn i 2016-2018 med spesialisthelsetjenesten: helseforetakenes somatiske akuttmottak og deres identifisering og behandling av pasienter med sepsis. Rapport 1/2018. Oslo: Helsetilsynet, 2018. https://www.helsetilsynet.no/publikasjoner/rapport-fra-helsetilsynet/rapport-fra-helsetilsynet-2018/se psis-ingen-tid-a-miste-oppsummering-av-tilsyn-med-spesialisthelsetjenesten-helseforetakenessomatiske-akuttmottak-og-deres-identifisering-og-behandling-av-pasienter-med-sepsis/(29-4.2019).

2. Knoop ST, Skrede S, Langeland N et al. Epidemiology and impact on all-cause mortality of sepsis in Norwegian hospitals: A national retrospective study. PLoS One 2017; 12: e018799o. [PubMed][CrossRef]

3. Dellinger RP, Levy MM, Rhodes A et al. Surviving sepsis campaign: international guidelines for management of severe sepsis and septic shock: 2012. Crit Care Med 2013; 41: 580-637.

[PubMed][CrossRef]

4. Trydal E, Martinsen AB, Beisland F et al. Strukturert mottak av sepsispasienter og oppstart av antibiotika. Tidsskr Nor Legeforen 2019; 139. doi: 10.4045/tidsskr.18.0216. [CrossRef]

5. Bone RC, Balk RA, Cerra FB et al. Definitions for sepsis and organ failure and guidelines for the use of innovative therapies in sepsis. Chest 1992; 101: 1644-55. [PubMed][CrossRef]

6. Askim Å, Moser F, Gustad LT et al. Poor performance of quick-SOFA (qSOFA) score in predicting severe sepsis and mortality - a prospective study of patients admitted with infection to the emergency department. Scand J Trauma Resusc Emerg Med 2017; 25: 56. [PubMed][CrossRef]

7. IDSA Sepsis Task Force. Infectious Diseases Society of America (IDSA) position statement: Why IDSA did not endorse the surviving sepsis campaign guidelines. Clin Infect Dis 2018; 66: 1631-5. [PubMed][CrossRef]

8. Vandvik PO. Har vi troverdige retningslinjer for klinisk praksis i Norge? Tidsskr Nor Legeforen 2018; 138. doi: 10.4045/tidsskr.18.0102. [PubMed][CrossRef]

Publisert: 27. mai 2019. Tidsskr Nor Legeforen. DOI: 10.4045/tidsskr.19.0320

(C) Tidsskrift for Den norske legeforening 2020. Lastet ned fra tidsskriftet.no 